the availability of donor organs, intensive care facilities, and staffing levels can be improved.

We thank our colleagues in anaesthetics, especially $\mathrm{Dr}$ Klinck; our pathologist, Dr D Wight; our radiologists; and the nursing staff of the paediatric unit. We also thank Mr B Allenstein, who developed the database system for this programme and greatly helped with the analysis of the data.

1 Starzl TE, Groth CG, Brettschneider L, Penn I, Fulginiti VA, Moon JB, et al Orthotopic homotransplantation of the human liver. Ann Surg 1968;168: 392-415.

2 Naional Instures of Heath Consensus Development. Conference satement liver transplantation-June 20-23. Hepatology 1984;4(suppl): 107-10.

3 Starzl TE, Koep LJ, Schroter GPJ, Halgrimson CG, Porter KA, Weil R. Liver replacement for pediatric patients. Pediatrics 1979;63:825-9.

4 Pett S, Pelham A, Tizard J, Barnes N, Mieli-Vergani G, Mowat AP, et al. Pediatric liver transplantation: Cambridge/King's series, December 1983 to August 1986. Transplant Proc 1987; 19:3256-60.

5 Kalayoglu M, Stratta RJ, Sollinger HW, Hoffman RM, D'Alessandro AM, Pirsch JD, et al. Liver transplantation in infants and children. $\mathcal{F}$ Pediatr Sur 1989;24:70-6.

6 Rolles K, Williams R, Neuberger J, Calne R. The Cambridge and King's College experience of liver transplantation 1968-1983. Hepatology 1984; 4(suppl 1):50-5.

7 Calne RY, ed. Liver transplantation-the Cambridge/King's College Hospital experience. 2nd ed. Orlando: Grune and Stratton, 1987.

8 Calne RY. A new technique for biliary drainage in orthotopic liver transplanta tion utilizing the gall bladder as a pedicle graft conduit between the dono and recipient common bile ducts. Ann Surg 1976;184:605-9.

9 Bismuth H, Houssin D. Reduced-sized orthotopic liver graft in hepatic transplantation in children. Surgery 1984;95:367-70.

10 Broelsch CE, Emond JC, Thistlethwaite JR, Rouch DA, Whitington PF, Lichtnr JL. Liver transplantation with reduced size donor organs. Transplantation 1988;45:519-23.

11 Coulden RA, Britton PD, Farman P, Noble-Jamieson G, Wight DGD. Preliminary report: hepatic vein Doppler in the early diagnosis of acute live transplant rejection. Lancet 1990;336:273-5.

2 Syndman DR, Werner BG, Heinze-Lacey B, Berardi VP, Tilney NL, Kirkman RL, et al. Use of cytomegalovirus immune globulin to preven cytomegalovirus disease in renal transplant recipients. $N$ Engl f Med 1987;317:1049-54.

13 Harper PL, Luddington RJ, Carrel RW, Barnes N, Edgar PF, Seaman MJ, et al. Protein $\mathrm{C}$ deficiency and portal thrombosis in liver transplantation in children. Lancet 1988 ;ii:924-7.

14 Noble-Jamieson G, Barnes ND, Thiru S, Mowat AP. Severe hypertension after liver transplantation in alpha-1-antitrypsin deficiency. Arch Dis Child 1990;65:1217-21.

15 Sokal EM, Veyckemans F, de Ville de Govet J, Moulin D, Van Hoorebeeck N,
Alberti D, et al. Liver transplantation in children less than 1 year of age. f Pediatr 1990;117:205-10.

16 Otte JB, de Ville de Goyet J, de Hemptinne B, Kestens PJ, Moulin D, Carlier $\mathrm{MA}$, et al. Liver transplantation in children: report of $2 \frac{1}{2}$ years' experience at the University of Louvain Medical School in Brussels. Transplant Proc 1987; 19:3289-302.

17 Mieli-Vergani G, Howard ER, Portmann B, Mowat AP. Late referral for biliary atresia-missed opportunities for effective surgery. Lancet 1989; 421-3.

18 Ohi R, Nio M, Chiba T, Endo N, Goto M, Ibrahim M. Long-term follow-up after surgery for patients with biliary atresia. $\mathcal{F}$ Pediatr Surg 1990;25:442-5.

19 De Hemptinne B, de Ville de Goyet J, Kestens PJ, Otte JB. Volume reduction of the liver graft before orthotopic transplantation: report of a clinical of the liver graft before orthotopic transplantation: $r$ repo

20 Mazzaferro V, Esquivel CO, Makowka L, Belle S, Kahn D, Koneru B, et al. Hepatic artery thrombosis after pediatric liver transplantation - a medical or Hepatic artery thrombosis after pediatric liver tran

21 Samuel D, Castaing D, Reynes M, Bismuth H. Portal and arterial thrombosi in liver transplantation: a frequent event in severe rejection. Transplant Proc 1989;21:2225-7.

22 Gartner JC, Zitelli BJ, Malatack JJ, Shaw BW, Iwatsuki S, Starzl TE Orthotopic liver transplantation in children: two year experience with 47 patients. Pediatrics 1984;74:140-

23 Andrews WS, Wanek E, Fyock B, Gray S, Benser M. Pediatric live transplantation: a 3-year experience. F Pediatr Surg 1989;24:77-82.

24 McDonald JA, Painter DM, Bell R, Gallagher ND, Sheil AGR, McCaughan GW. Human liver allograft rejection: severity, prognosis and response to treatment. Transplant Proc 1989;21:3792-3.

25 Salt A, Sutehall G, Sargaison M, Woodward C, Barnes ND, Calne RY, et al. Viral and toxoplasma gondii infections in children after liver transplantation. f Clin Pathol 1990;43:63-7.

26 Stratta RJ, Shaefer MS, Markin RS, Wood RP, Kennedy EM, Langnas AN et al. Clinical patterns of cytomegalovirus disease after liver transplantation. Arch Surg 1989;124:1443-9.

27 Weimar W, Metselaar HJ, Balk AH, Mochtar B, Rothbarth PhH, Jeekel J. Passive immunization to prevent cytomegalovirus disease after kidney and heart transplantation. Transplant Proc 1990;22:229-32.

28 Salmela K, Hoeckerstedt K, Lautenschlager I, Eklund B, Isoniemi H, Holmberg C, et al. Ganciclovir in the treatment of severe cytomegalovirus disease in liver transplant patients. Transplant Proc 1990;22:238-40.

29 Oguma S, Belle S, Starzl TE, Demetris AJ. A histometric analysis of chronically rejected human liver allografts: insights into the mechanisms of bile duct loss: direct immunologic and ischaemic factors. Hepatolog 1989;9:204-9.

30 Foegh ML. Chronic rejection-graft arteriosclerosis. Transplant Proc 1990;22: $119-22$

31 Starzl TR, Fung J, Venekataramman R, Todo S, Demetris AJ, Jain A. FK506 for liver, kidney and pancreas transplantation. Lancet 1989;ii:1000-4.

32 Hubscher SG, Buckles JAC, Elias E, McMaster P, Neuberger JM. Reversible vanishing bile duct syndrome after liver transplantation: report of six cases. Transplant Proc 1991;23:1415-6.

(Accepted 4 November 1991)
Joyce Green Hospital,

Dartford, Kent

Christine Hardy-

Thompson, MB, senior house

officer in psychiatry

\section{Maudsley Hospital,}

Denmark Hill, London SE5

Martin W Orrell, MRCPSYCH, senior registrar

Klaus Bergmann, MD,

consultant psychiatrist

Correspondence to: $\mathrm{Dr}$ Orrell.

$B M \mathcal{F} 1992 ; 304: 421-2$

\section{Evaluating a psychogeriatric domiciliary visit service: views of general practitioners}

\section{Christine Hardy-Thompson, Martin W Orrell, Klaus Bergmann}

The value of the domiciliary consultation service has recently been questioned ${ }^{1}$ in view of the increasing cost from $£ 10 \mathrm{~m}$ in 1983 to $£ 20 \mathrm{~m}$ in $1988^{23}$ despite a decrease in the use of the service. General practitioner fundholding will obviously exert an influence on the future use of domiciliary visits. A recent review of general practitioners' referrals showed how little is understood about the correct level of service. ${ }^{4}$ Nevertheless, domiciliary consultations are a major component of a modern psychogeriatric service and may be preferred for new referrals. To plan or evaluate services it is vital to know the needs of general practitioners; we therefore investigated general practitioners' views and use of psychogeriatric domiciliary consultations.

\section{Subjects, methods, and results}

To assess the requirements for a successful domiciliary visit we interviewed the two local psychogeriatric consultants and a random sample of $10(10 \%)$ local general practitioners. This pilot study was used to compile a questionnaire, which was sent to all 105 general practitioners in the same catchment area.
We received $85(81 \%)$ completed replies. In all, 70 general practitioners had initiated one or more psychogeriatric domiciliary visits in the previous six months but only 19 had attended any. Several general practitioners commented that vague or awkward timing of the consultation often made it difficult to attend. The table gives the factors that general practitioners considered important in their decision to request a domiciliary visit in preference to another type of assessment. Forty thought the visit would often result in inpatient admission but only four always expected an admission.

Number of general practitioners ( $n=85$ ) who rated various factors a "essential" or "very important" in influencing their decision to request a domiciliary visit

Factor $\quad \begin{gathered}\text { No of } \\ \text { general } \\ \text { practitioners }\end{gathered}$

Home circumstances influencing mental health or management Patient's physical ill health

Patient's physical disability

Patient's interaction with family/cohabitee at home

To obtain a consultant's opinion

Because a domiciliary visit facilitates admission Pressure from relatives

Fifty six of the general practitioners said that they had usually seen the patient the same day as the request for a visit was made, 67 said that a psychogeriatric domiciliary visit service was very important to their work, and 59 were very satisfied with the present service. Both psychogeriatric consultants agreed that a proper assessment for dementia meant seeing the patient's home and an informant. They valued the 
presence of the general practitioner to discuss shared care and to help avoid admission and emphasised the importance of providing support to the relatives by giving the details of local groups and services and counselling them about the illness.

\section{Comment}

Domiciliary visits are primarily intended to provide specialist advice when the patient cannot attend hospital for medical reasons. Although general practitioners valued the visits, they attended them infrequently and did not view them as a true consultation. Part of the problem may have been the timing. The need for an assessment of the patient's home situation was seen as at least as important as the patient's physical or psychiatric condition in the general practitioner's decision to request a domiciliary visit.

Evaluation of a domiciliary visit service through peer review and feedback can reduce the number of requests and the cost to a health authority. ${ }^{3}$ But how effective will this be with elderly patients when many of those considered by their general practitioner to require urgent admission do not need it according to

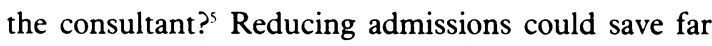
more money than merely decreasing the number of domiciliary visits. Our findings highlight different approaches in providing services for elderly mentally ill people. Either the consultant can have a liaison role, advising the general practitioner and facilitating participation of other services and professionals in the patient's care in the community, or the consultant psychogeriatrician and multidisciplinary team can take over. The first approach requires more community resources but the second suggests an expansion of hospital related services. The ambiguities in the domiciliary visit service shown by this study suggest that the dilemma is far from over.

We thank all the doctors who participated in this study.

1 Forsythe $M$. Domiciliary visits. $B M f$ 1991;302:426-7.

2 Dowie R. National trends in domiciliary consultations. BMf 1983;286:819-21.

3 Donaldson LJ, Hill PM. The domiciliary consultation service: time to take stock. $B M 7$ f 1991; 302:449-51.

4 Wilkin C, Dornan D. General practitioner referrals to hospital - a review of it's research and it's implications for policy and practice. London: Department of Health, 1990.

5 Bendall MJ. Changing work pattern in a geriatric unit and the effect of a day hospital. Age Ageing 1978;7:229-32.

(Accepted 5 September 1991)

\section{Underreporting of pedestrian road accidents}

\section{David Teanby}

Mersey Region Trauma Survey, Warrington General Hospital, Warrington WA5 1QG David Teanby, FRCS, research fellow

B.MF 1992:304:422
Road accidents to pedestrians caused 1706 deaths and 58374 injuries in Great Britain during 1989.' These figures and other data used for road planning and safety campaigns are derived from accident data supplied by the police. I assessed the completeness of police recording by comparing their figures on accidents to pedestrians with data from a regional database of trauma care.

\section{Methods and results}

A one year review (May 1989-April 1990) of trauma care within Mersey region, North Wales, and the Isle of Man was conducted by using information from ambulance services, accident departments, and coroners. All pedestrian accidents that occurred within the Merseyside police area were then analysed in detail.

For 85 cases where pedestrians were killed or severely injured (injury severity score $>15)^{2}$ and where there was information on the site, date, and time of the accident we tried to correlate individual cases with those recorded by Merseyside Police central statistics unit. The unit records details of the site of the accident but not the names and addresses of the victims to maintain confidentiality.

Fourteen of the patients could not be identified in police records. Two of these 14 patients had died, one shortly after arriving at the accident department and one after surviving in a coma for three months. One was aged 74 and the other 82 and their injury severity scores were 38 and 59 (median 48). The 12 survivors had a mean age of 45 years (range 7-78), a median severity score of 32 (17-50), and occupied 1037 hospital bed days with a mean length of stay of 86 days (6-246).

The patients whose details were recorded by the police were generally younger. Of the 50 who died, 15 died at the scene of the accident (mean age 41.3 years (6-80); median severity score 45 (19-75)) and 35 died in hospital (mean age 49.4 years (3-93); median severity score 43 (13-75)) with a mean survival of five days $(0-49)$. The mean age of the 21 survivors was $36 \cdot 2$ years (4-78), their median severity score 27 (17-50), and length of stay 61 days (13-197).

We could not validate details held by the police against our survey database because of the wide definition of serious injury used by the police.

\section{Comment}

Government statistics on accidents, traffic planning, and highway design are derived from data collected by the police on road accident report form (STATS 19). In our survey Merseyside Police data underrecorded pedestrian accidents by $16 \%$. If this figure applies nationally up to 10000 casualties a year may be excluded from government statistics.

Accidents that cause trivial or no injuries are often not reported, and allowance is made for these. The underreporting of serious and fatal accidents, however, may lead to flaws in planning.

Details of emergency calls to accidents are routinely passed between the emergency services, but data may not reach police statistics for several reasons. Some accident victims may be driven to hospital by private vehicle (the ambulance service industrial dispute coincided with part of the study period) with no emergency call being made; accident victims may decline police involvement; and a few cases may be lost in administration before reaching the statistical unit.

Information on road traffic accidents is collected by hospitals to allow them to charge for emergency treatment. This information too is often incomplete, but there is no mechanism for passing it to a central statistical unit. Central registration, either nationally or regionally, of hospital road accident data may allow them to be collated with information from the police and coroners to provide a more complete picture of road accidents in Great Britain.

\footnotetext{
1 Department of Transport. Road accidents Great Britain 1989. The casualty report. London: HMSO, 1990:47-52.

2 Baker SP, O'Neill B, Haddon W, Long WB. The injury severity score: method for describing patients with multiple injuries and evaluating
} emergency care. Fournal of Trauma 1974;14:187-96.

(Accepted 4 September 1991) 